\title{
Keeping it real: MRX-Sae2 clipping of natural substrates
}

\author{
Robert Gnügge and Lorraine S. Symington \\ Department of Microbiology and Immunology, Columbia University Medical Center, New York, New York 10032, USA
}

\begin{abstract}
The yeast Mre11-Rad50-Xrs2 (MRX) complex and Sae2 function together to initiate DNA end resection, an essential early step in homology-dependent repair of DNA double-strand breaks (DSBs). In this issue of Genes \& Development, Wang and colleagues (pp. 2331-2336) and Reginato and colleagues (pp. 2325-2330) report that a variety of physiological protein blocks, including Ku, RPA, and nucleosomes, stimulate MRX-Sae2 endonuclease cleavage in vitro. These studies have important implications for how cells deal with a range of barriers to end resection and highlight the crucial role of Sae 2 in activating MRX cleavage at the correct cell cycle stage.
\end{abstract}

Chromosomal double-strand breaks (DSBs) are toxic DNA lesions that must be accurately repaired to maintain genome integrity; failure to properly mend DSBs can result in loss of genetic information, chromosome rearrangements, or even cell death. Typically, cells repair DSBs by nonhomologous end joining (NHEJ) or homologous recombination (HR). NHEJ directly ligates DSB ends, whereas HR uses extensive homology and templated DNA synthesis to restore the broken chromosome. HR is activated during the $S$ and $G 2$ phases of the cell cycle to ensure error-free repair from a sister chromatid template. HR initiates by nucleolytic degradation of the $5^{\prime}$ terminated strands in a process termed end resection (for review, see Symington 2016). End resection generates 3' ssDNA tails, substrates for Rad51 to catalyze homologous pairing and exchange of DNA strands and for activation of the DNA damage checkpoint.

Genetic studies in yeast implicate the Mre11-Rad50Xrs2 (MRX) complex and Sae2 in early steps of resection (Xrs2 and Sae2 are replaced by NBS1 and CtIP, respectively, in mammalian cells). In vitro, Mre11 exhibits $3^{\prime}-5^{\prime}$ dsDNA-specific exonuclease and ssDNA-specific endonuclease activities (Paull and Gellert 1998). The current model for resection initiation is by MRX-catalyzed incision of the $5^{\prime}$-terminated strands internal to the ends in a reaction stimulated by cyclin-dependent kinase (CDK)

[Keywords: nuclease; MRX-Sae2; Ku70-Ku80; RPA; nucleosome; homologous recombination; DNA end resection]

Corresponding author: 1ss5@columbia.edu

Article is online at http://www.genesdev.org/cgi/doi/10.1101/gad.310771. 117. phosphorylated Sae2 (Huertas et al. 2008; Cannavo and Cejka 2014). The resulting nicks are entry sites for the Mre11 3' exonuclease to degrade back to the DSB and for more extensive processing of $5^{\prime}$ strands by either Exo1, a $5^{\prime}-3^{\prime}$ exonuclease, or the combined activities of the Sgs1 helicase and the Dna2 endonuclease (Fig 1; Garcia et al. 2011).

Previous biochemical studies by Cannavo and Cejka (2014) demonstrated that biotin-streptavidin linkages at the ends of linear duplex substrates induced MRX endonucleolytic cleavage of the 5 ' strands in a reaction stimulated by Sae2. This observation raised the question of whether physiological protein blocks would also stimulate MRXSae2-catalyzed incision. The Ku complex, an essential component of the NHEJ pathway, is rapidly recruited to DSBs in cells and protects ends from degradation by Exo1 (Symington 2016). In the accompanying studies (Reginato et al. 2017; Wang et al. 2017), the investivators show that $\mathrm{Ku}$ is as effective as biotin-streptavidin in stimulating endonucleolytic cleavage by MRX-Sae2 (Fig 1). Furthermore, Ku inhibited Mre11-catalyzed 3'-5' degradation at DNA ends. In agreement with previous work, the clipping reaction depended on ATP hydrolysis by Rad50 and phosphorylated Sae2. These findings are consistent with cooperation between $\mathrm{Ku}$ and MRX to promote NHEJ in G1-phase cells, whereas, in S-G2-phase cells, when a sister chromatid is available and Sae2 is activated by $\mathrm{CDK}, \mathrm{Ku}$ stimulates endonucleolytic clipping by MRX-Sae2, thereby committing cells to HR.

Binding of RPA to ssDNA overhangs had an effect similar to that of $\mathrm{Ku}$ binding; exonucleolytic degradation was impeded, while endonucleolytic scission was stimulated. Additionally, Wang et al. (2017) used substrates with terminal hairpin structures and found that RPA binding enhanced MRX-Sae2 clipping next to the structures. These data support a model in which the MRX complex can reinitiate resection in case the long-range resection machinery becomes disengaged or encounters an obstacle and have important implications for removal of fold-back

(C) 2018 Gnügge and Symington This article is distributed exclusively by Cold Spring Harbor Laboratory Press for the first six months after the fullissue publication date (see http://genesdev.cshlp.org/site/misc/terms. xhtml). After six months, it is available under a Creative Commons License (Attribution-NonCommercial 4.0 International), as described at http://creativecommons.org/licenses/by-nc/4.0/. 


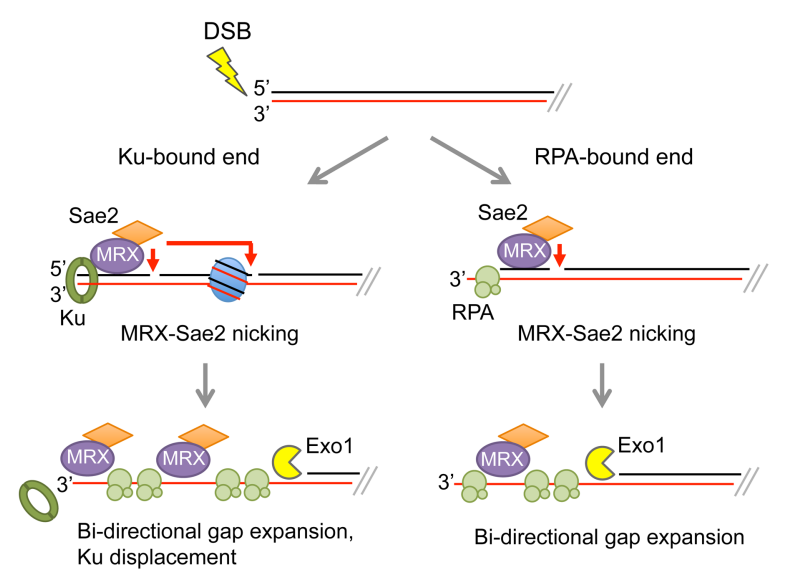

Figure 1. The MRX-Sae2 nuclease nicks 5 '-terminated strands of DSBs at diverse protein barriers. In S-G2-phase cells, Sae2 is phosphorylated by CDK and activates the MRX endonuclease to incise $5^{\prime}$-terminated strands at $\mathrm{Ku}$ - or RPA-bound ends or adjacent to nucleosomes. The MRX $3^{\prime}-5^{\prime}$ exonuclease and the Exol $5^{\prime}-3^{\prime}$ exonuclease expand the resulting nicks to create long tracts of ssDNA for HR. MRX $3^{\prime}-5^{\prime}$ degradation is anticipated to displace $\mathrm{Ku}$ from ends. Note that only one side of a DSB is shown.

structures that are precursors to palindromic duplications and other complex rearrangements.

DSB processing in cells impaired for long-range resection as well as recent genome-wide resection analysis in meiotic cells suggested that MRX-Sae2 nicking occurs preferentially between nucleosomes (Mimitou and Symington 2008; Zhu et al. 2008; Mimitou et al. 2017). To test this hypothesis using their in vitro system, Wang et al. (2017) positioned a single nucleosome on a 232base-pair substrate. Indeed, they identified novel scission sites corresponding to MRX-Sae2 cleavage adjacent to the nucleosome (Fig 1). These data nicely explain the 100- to 200-nucleotide incremental cleavages detected at endonuclease-induced DSBs in exo1 $1 \Delta$ sgs $1 \Delta$ cells.

The bidirectional resection model posits that the Mre11 $3^{\prime}-5^{\prime}$ exonuclease chews back from the MRX-Sae2-generated nick and that Exo1 degrades the $5^{\prime}$-terminated strand (Garcia et al. 2011; Symington 2016). Importantly, Reginato et al. (2017) show that Exol efficiently degrades from the nick generated by MRX-Sae2 in a coupled reaction. The bacteriophage T7 exonuclease was ineffective in chewing from the MRX-Sae2-catalyzed nick even though it showed activity equivalent to that of Exol at DNA ends and nicks. By devising a substrate with an internal nick, Wang et al. (2017) were able to demonstrate a stimulatory role for Sae2 in Mre11-catalyzed degradation from the nick. In contrast to MRX incision, this activity was not dependent on phosphorylated Sae 2 or Rad50 ATPase activity. Together, these findings provide strong biochemical support for the bidirectional resection model.

The studies by Wang et al. (2017) and Reginato et al. (2017) demonstrate how MRX-Sae2 interacts with natural proteins bound to DSB ends and with the long-range machinery and confirm the importance of Sae2 to restrict resection initiation to the appropriate cell cycle stage. The findings raise several interesting questions: How is the endonuclease activity of MRX controlled not only temporally but also locally to the vicinity of DSB ends? Given that MRX-Sae2 is able to incise the 5' DNA strand next to a multitude of stably bound protein obstacles, such as nucleosomes and RPA, how is spurious nicking prevented? It also remains to be determined how Sae2 and Rad50 coordinate to target Mre11 nicking to the $5^{\prime}$-terminated strands at DSBs.

\section{Acknowledgments}

Studies in the Symington laboratory are supported by grants from the National Institutes of Health (GM041784 and CA174653).

\section{References}

Cannavo E, Cejka P. 2014. Sae2 promotes dsDNA endonuclease activity within Mre11-Rad50-Xrs2 to resect DNA breaks. $\mathrm{Na}$ ture 514: 122-125.

Garcia V, Phelps SE, Gray S, Neale MJ. 2011. Bidirectional resection of DNA double-strand breaks by Mre11 and Exol. Nature 479: 241-244.

Huertas P, Cortes-Ledesma F, Sartori AA, Aguilera A, Jackson SP. 2008. CDK targets Sae2 to control DNA-end resection and homologous recombination. Nature 455: 689-692.

Mimitou EP, Symington LS. 2008. Sae2, Exo1 and Sgs1 collaborate in DNA double-strand break processing. Nature 455: 770-774.

Mimitou EP, Yamada S, Keeney S. 2017. A global view of meiotic double-strand break end resection. Science 355: 40-45.

Paull TT, Gellert M. 1998. The 3' to $5^{\prime}$ exonuclease activity of Mre 11 facilitates repair of DNA double-strand breaks. Mol Cell 1: 969-979.

Reginato G, Cannavo E, Cejka P. 2017. Physiological protein blocks direct the Mre11-Rad50-Xrs2 and Sae2 nuclease complex to initiate DNA end resection. Genes Dev (this issue). doi: $10.1101 /$ gad.308254.117.

Symington LS. 2016. Mechanism and regulation of DNA end resection in eukaryotes. Crit Rev Biochem Mol Biol 51: 195-212.

Wang W, Daley JM, Kwon Y, Krasner DS, Sung P. 2017. Plasticity of the Mre11-Rad50-Xrs2-Sae2 nuclease ensemble in the processing of DNA-bound obstacles. Genes Dev (this issue). doi: 10.1101/gad.307900.117.

Zhu Z, Chung WH, Shim EY, Lee SE, Ira G. 2008. Sgs1 helicase and two nucleases Dna2 and Exo1 resect DNA double-strand break ends. Cell 134: 981-994. 


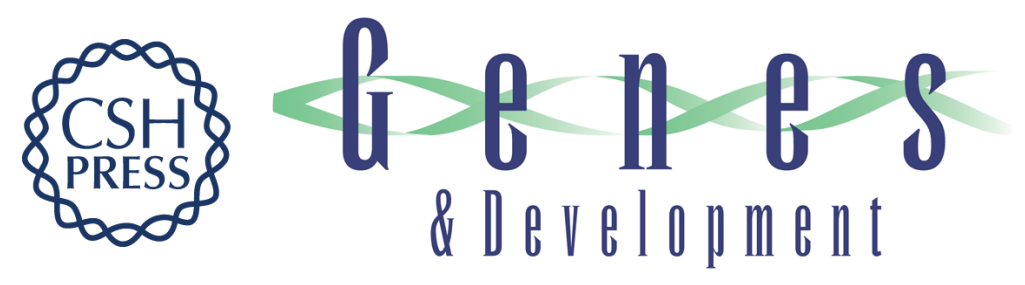

\section{Keeping it real: MRX-Sae2 clipping of natural substrates}

Robert Gnügge and Lorraine S. Symington

Genes Dev. 2017, 31:

Access the most recent version at doi:10.1101/gad.310771.117

\section{Related Content Physiological protein blocks direct the Mre11Rad50Xrs2 and Sae2 nuclease complex to initiate DNA end resection Giordano Reginato, Elda Cannavo and Petr Cejka Genes Dev. December, 2017 31: 2325-2330 Plasticity of the Mre11Rad50Xrs2Sae2 nuclease ensemble in the processing of DNA-bound obstacles Weibin Wang, James M. Daley, Youngho Kwon, et al. Genes Dev. December , 2017 31: 2331-2336}

References This article cites 10 articles, 3 of which can be accessed free at: http://genesdev.cshlp.org/content/31/23-24/2311.full.html\#ref-list-1

Articles cited in: http://genesdev.cshlp.org/content/31/23-24/2311.full.html\#related-urls

Creative This article is distributed exclusively by Cold Spring Harbor Laboratory Press for the first Commons six months after the full-issue publication date (see License http://genesdev.cshlp.org/site/misc/terms.xhtml). After six months, it is available under a Creative Commons License (Attribution-NonCommercial 4.0 International), as described at http://creativecommons.org/licenses/by-nc/4.0/.

Email Alerting Receive free email alerts when new articles cite this article - sign up in the box at the top Service right corner of the article or click here.

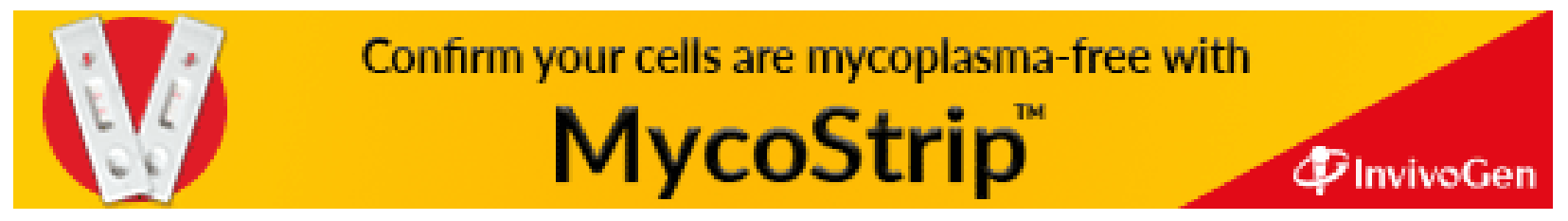

